\title{
Effect of Lawsonia inermis Linn. Ethanol Extract on the Superoxyde Dismutase Activity in Hyperglycemic Rattus norvegicus
}

\author{
Maya Anjelir Antika'), Syafruddin Ilyas², Mutiara Indah Sari3) \\ 1) Masters Program of Biomedical, Faculty of Medicine, University of North Sumatra \\ 2)Biology Departement, FMIPA, University of North Sumatra \\ 3) Biochemistry Departement, Faculty of Medicine, North Sumatra University
}

\begin{abstract}
Background: Alloxan causes experimental diabetic conditions (hyperglycemia) in experimental animals through oxidation and the formation of free radicals (oxidative stress) that damage pancreatic $\beta$ cells. The ethanol extract of the henna leaves can decrease oxidative stress. The purpose of this study is to know the effect of ethanol extract of henna leaves to decrease blood sugar level and increase superoksida enzyme activity.

Subjects and Methods: This study is an experimental study. The study design of posttest only control group design, using mice (Rattus norvegicus) strains of wistar, was randomized in five groups: negative control, positive control, group obtaining ethanol extract of henna leaves $200 \mathrm{mg} / \mathrm{kg} \mathrm{BW}, 400 \mathrm{mg} / \mathrm{kg} \mathrm{BW}$ and $600 \mathrm{mg} / \mathrm{kg} \mathrm{BW}$.

Results: This study showed a significant reduction in blood glucose levels when compared to the control group. Superoxide dismutase enzyme activity increased but was not statistically significant.

Conclusion: Ethanol extract of henna leaves $400 \mathrm{mg} / \mathrm{kg}$ BW significantly decreased mice blood glucose level, there was no significant difference in the increase of superoxide dismutase enzyme activity.
\end{abstract}

Keywords: Alloxan, antioxidant, flavonoids, hyperglycemia, oxidative stress.

\section{Correspondence:}

Maya Anjelir Antika. Masters Program of Biomedic, Faculty of Medicine, University of North Sumatera.

\begin{abstract}
BACKGROUND
Persistent hyperglycemia in people with diabetes mellitus (DM) is a risk factor associated with increased oxidative stress due to an imbalance between free radicals and natural antioxidants formed by the body. Increased oxidative stress can occur in insulin dependent diabetes mellitus (IDDM) or type I DM and non insulin dependent diabetes mellitus (NIDDM) or type II DM. In type I DM, oxidative stress destroys pancreatic $\beta$ cells while in type II $\mathrm{DM}$, it will cause impaired insulin production, release, and insulin function (Sheikhpour, 2013). Alloxan compounds
\end{abstract}

$\left(\mathrm{C}_{4} \mathrm{H}_{2} \mathrm{~N}_{2} \mathrm{O}_{4}\right)$ are one of the toxic diabetogenic substances, especially to pancreatic beta cells, and when given to experimental animals such as mice, it can cause miceto-diabetic animals (Prameswari et al., 2014). Alloxan may be administered intravenously, intraperitoneally, or subcutaneously to experimental animals (Goyal et al., 2016).

Oxidative stress is an imbalance between free radical production or reactive oxygen species (ROS) with antioxidants, which free radical levels are higher than antioxidants (Kurkcu, 2010). The high oxidative stress that lasts longer 
Indonesian Journal of Medicine (2017), 2(2): 79-85

https://doi.org/10.26911/theijmed.2017.02.02.01

will cause cell membrane lipid peroxidation, autocesidation reaction, apoptosis, deoxyribo nucleic acid (DNA) damage and cause of degenerative diseases one of which is diabetes (Kothari et al., 2010).

Diabetes mellitus (DM) is a metabolic disorder in the body characterized by elevated blood glucose levels (hyperglycemia) because there are abnormallities of metabolism pathways of carbohydrates, fats and proteins caused by insulin secretion abnormalities, insulin work, or both (ADA, 2014) .

Diabetes mellitus can be caused by many factors, one of which is free radical (oxidative stress). If the hormone insulin is lacking or not available in the body, then glucose in the blood can not enter the cell causing high glucose levels in blood or hyperglycemia. Normal fasting blood glucose levels in humans range from 80$110 \mathrm{mg} / \mathrm{dL}$, and normal blood glucose levels in mice 95-125 mg/dL (Suarsana et al., 2010). The condition of hyperglycemia will lead to glucose autooksidation reactions, protein glycation and activation of polyol metabolism pathways that will accelerate the formation of free radicals and cause the formation of oxidative stress (Jameson, 2010). The rate of oxidative stress in DM patients has proven to be higher than in normal conditions (Sunyoto, 2015).

Giving antioxidants according to Siahaan et al., (2016) can bind free radicals that can reduce the risk of DM. The body has an antidote to overcome free radicals in the form of endogenous antioxidant enzymes (Wresdiyati et al., 2008; Astuti et al., 2009). The mechanism of the body's natural defense system is the endogenous antioxidant enzyme, superoxide dismutase (SOD), catalase (Cat), and glutathione peroxidase (GPx) (Suarsana et al., 2010). Cells will be protected from oxidative stress condition by SOD by catalyzing the dismutase of superoxide anions (O2-) to $\mathrm{O}_{2}$ and $\mathrm{H}_{2} \mathrm{O}$. Superoxide dismutase (SOD) levels in mouse liver tissue under stress conditions indicate a decrease (Rahmawati et al., 2014).

Decreasing levels of SOD under stress conditions was not expected, given the function of SOD as an antioxidant superoxide radical counterterative that amounts increased in conditions of oxidative stress. Therefore, it was necessary to increase the levels of SOD by consuming food containing exogenous antioxidants. Oxidative stress conditions require antioxidants from the outside (exogenous). Some products of natural compounds such as flavonoids, coumarins, curcuminoids or terpenoids, isolated from plants have shown strong antioxidant activity and low toxicity (Yang et al., 2007).

Antioxidants from the outside (exogenous) can be obtained from plants rich in antioxidants one of which is the henna plant (Lawsonia inermis Linn.). The plant (Lawsonia inermis Linn.) has been used to treat various diseases such as liver damage, rheumatoid arthritis, headache, diarrhea, leprosy, fever, heart disease, boils and diabetes (Sanni et al., 2010; Choubey, 2010; Goswami et al., 2011). Based on phytochemical screening, the leaf contains phenolic compounds (coumarin, flavonoid, naphthalene, lawsone, gallic acid derivatives) and glycosylated protein (Hsouna et al., 2011).

Based on Choubey's study (2010) concluded that giving of ethanol extract of henna leaves (Lawsonia inermis Linn.) $500 \mathrm{mg} / \mathrm{kgbb}$ for 28 days effectively decreased blood glucose level of mice. Study from Chikaraddy et al., (2012), stated that the ethanol extract of henna 
leaves (Lawsonia inermis Linn.) with dose of $150 \mathrm{mg} / \mathrm{kg} \mathrm{BW}, 200 \mathrm{mg} / \mathrm{kg} \mathrm{BW}$ and $400 \mathrm{mg} / \mathrm{kg}$ BW for 3 weeks could decrease blood sugar levels of albino mice.

Ethanol extract of henna leaves with $400 \mathrm{mg} / \mathrm{kg}$ BW showed significant changes in decreasing blood sugar levels compared with doses of $150 \mathrm{mg} / \mathrm{kg} \mathrm{BW}$ and $200 \mathrm{mg} / \mathrm{kg} \mathrm{BW}$. The Ojewunmi et al. (2013) study demonstrated that 100 $\mu \mathrm{g} / \mathrm{ml} \mathrm{DPPH}$ of free activity of inhaled Lawsonia radical showed a maximum inhibition of $77.39 \%, 50.78 \%$ and $83.18 \%$ in lipid and nitric oxide peroxidation in vitro. Treatment of ethanol extract of henna leaves given orally for 21 days showed a significant decrease in blood glucose levels ( $\mathrm{p}<0.001$ ) compared with control of untreated diabetes. Stangeland et al., (2009) mentioned a decrease in blood glucose levels would minimize the risk of oxidative stress in cells and tissues.

Natural antioxidants contained in the henna leaf extracts such as phenolic flavonoids and alkaloids, can play an important role in health. The active compounds of these natural materials have been studied to have antidiabetic activity (Cing, 2010).

The active compound in the leaf can be extracted by using a particular solvent. According to Lukiati (2012) the solvent commonly used for the extraction of natural materials is ethanol because it is better than the water solvent, commonly used as a drug preliminary analysis and safe for further consumption. Ethanol will attract phenolic compounds, flavonoids, steroids, alkaloids and tannins. In addition, alcohol is an excellent multipurpose solvent for the extraction of polar compounds and non-polar compounds (Harborne, 1984).

Henna leaf extract is expected to be developed as a phytopharmaca, and used for the management of blood glucose levels in inhibiting further complications (Gayatri, 2012). As a lot of benefits of henna leaf and the public have not got scientific information related to the content of antioxidants and the properties of these plants, especially diseases caused by free radicals, in addition to previous studies are still examining the effects of antioxidants to mice liver, no reports about the efficacy of henna leaf in coping with stress oxidative action in the pancreas in hyperglycaemia condition.

The purpose of this study is to analyze the effect of ethanol extract of henna leaves to superoxide dismutase (SOD) activity of wistar hyperglycemic mice.

\section{SUBJECTS AND METHOD}

The study was an experimental study, with study design of post-test only control group design in wistar mice, divided into 4 groups: negative control group, positive control group (alloxan $120 \mathrm{mg} / \mathrm{kg} \mathrm{BW}$ ), group receiving alloxan of $120 \mathrm{mg} / \mathrm{kg}$ and ethanol extract of henna leaves of 200 $\mathrm{mg} / \mathrm{kg} \mathrm{BW}$; the group receiving alloxan of $120 \mathrm{mg} / \mathrm{kg}$ and ethanol extract of henna leaves of $400 \mathrm{mg} / \mathrm{kg} \mathrm{BW}$; and the group receiving alloxan of $120 \mathrm{mg} / \mathrm{kg}$ and ethanol extract of henna leaf of 600 $\mathrm{mg} / \mathrm{kg} \mathrm{BW}$.

Mice (Rattus norvegicus) strain wistar hyperglycemia within two days after giving alloxan, blood sugar $\geq \mathbf{2 5 0}$ $\mathrm{mg} / \mathrm{dl}$. After the blood sugar level increased, then given ethanol extract of leaf of hen for 28 days. SOD serum mice was tested by using the Enzy ChromTM Superoxide Dismutase Assay Kit (ESOD100) on the 29th day. 


\section{RESULTS}

Blood sugar level of normal mice was measured by Glucometer. Results of blood glucose level of mice could be seen in Picture 1.

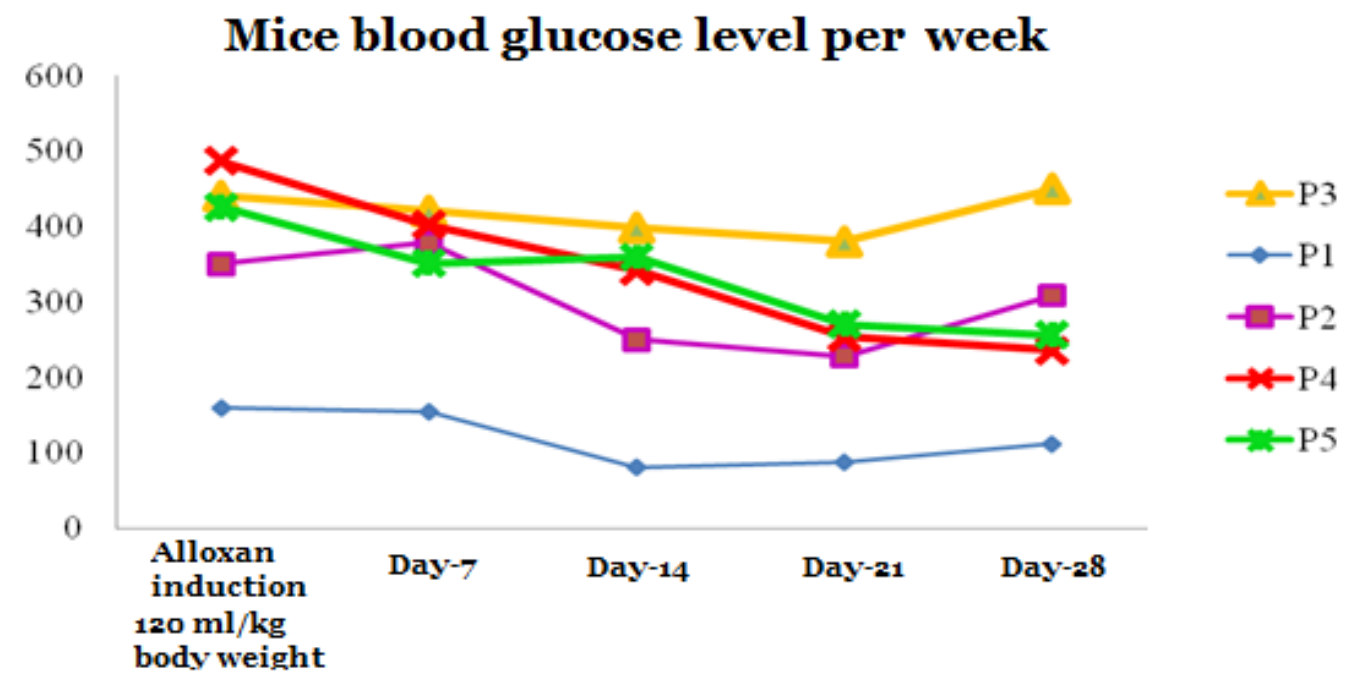

\section{Picture 1. Blood glucose level diagram of rats per week}

Description: $\mathrm{P} 1$ (negative control), $\mathrm{P}_{2}$ (positive control), $\mathrm{P}_{3}$ (ethanol extract of henna leaves $200 \mathrm{mg} / \mathrm{kg} \mathrm{BW}$ ), $\mathrm{P}_{4}$ (ethanol extract of henna leaves $400 \mathrm{mg} / \mathrm{kg} \mathrm{BW}$ ), $\mathrm{P}_{5}$ (ethanol extract of henna leaves $600 \mathrm{mg} / \mathrm{kg} \mathrm{BW}$ ).

Based on picture 1, it appeared that giving alloxan could damage pancreatic $\beta$ cells characterized by increasing KGD. $\mathrm{P} 1$ KGD group which was not alloxaninduced did not increase, whereas alloxan-induced $\mathrm{P}_{2}, \mathrm{P}_{3}, \mathrm{P}_{4}$ and $\mathrm{P}_{5}$ were increasing. On the 7 th day, $\mathrm{P}_{3}, \mathrm{P}_{4}$ and $\mathrm{P}_{5}$ groups were decreasing in KGD compared bybefore giving the extract of henna leaf, while P1 control group was negative and $\mathrm{P} 2$ positive control increased. On the 14th day, $\mathrm{P}_{1}$ and $\mathrm{P}_{2}$ groups were decreasing in KGD as well as $\mathrm{P}_{3}$ and $\mathrm{P}_{4}$, while $\mathrm{P}_{5}$ did not increase significantly. On the 21st day KGD groups $\mathrm{P}_{2}, \mathrm{P}_{3}, \mathrm{P}_{4}$ and $\mathrm{P}_{5}$ decreased while $\mathrm{P} 1$ group increased. On day 28 KGD $\mathrm{P}_{4}$ and $\mathrm{P}_{5}$ group decreased while $\mathrm{P}_{1}, \mathrm{P}_{2}$ and $\mathrm{P}_{3}$ group increased.

Blood glucose levels between groups were significantly different, which significant decreases occurred in the group given ethanol extract of henna leaves 200
$\mathrm{El} / \mathrm{kg} \mathrm{BW}, 400 \mathrm{mg} / \mathrm{kg} \mathrm{BW}$, and $600 \mathrm{mg} /$ $\mathrm{kg}$ BW. The group receiving a dose of $400 \mathrm{mg} / \mathrm{kg}$ BW had the lowest decrease (significant), this result was similar to Chikaraddy et al. (2012).

\section{DISCUSSION}

The decrease of KGD in the treatment group given ethanol extract of henna leaf can be caused by bioactive compounds contained in the ethanol extract of henna leaf that can prevent the occurrence of oxidation in pancreatic $\beta$ cells so the damage can be reduced. The bioactive compounds contained in the ethanol extract of henna leaf are based on phytochemical screening such as polyphenols, flavonoids, alkaloids and tannins. The role of polyphenols is thought to be capable of protecting pancreatic $\beta$ cells from the effects of free radical toxicity produced under chronic hyperglycemia conditions, 
but it also plays a role in lowering blood sugar levels (Ridwan et al., 2012).

Alkaloid is an antioxidant that can reduce free radicals due to giving alloxan. Tanin has antioxidant activity by inhibiting tumor growth and hypoglycemic activity by increasing glycogennesis. Flavonoids can prevent complications by clearing excessive free radicals, breaking the chain of free radical reactions, binding metal ions and inhibiting polyol pathways through inhibition of aldose reductase enzyme (Prameswari et al., 2014).

The decrease in KGD in $\mathrm{P} 2$ group occured due to the physiological selfhealing mechanism by repairing pancreatic $\beta$ cells and new cell division (mitosis) that progressed in stages.

Based on the result of the study, the measurement data of superoxide dis-

Table 1. Data analysis result of superoxide dismutase enzyme activity (SOD) after treatment for 28 days

\begin{tabular}{llc}
\hline Group & Rate \pm SD $(\mathbf{U} / \mathbf{m l})$ & p \\
\hline P1 & $30.79 \pm 4.18$ & \\
P2 & $29.62 \pm 3.51$ & 0.992 \\
P3 & $29.70 \pm 4.23$ & \\
P4 & $30.44 \pm 2.64$ & \\
P5 & $29.58 \pm 4.34$ & \\
\hline
\end{tabular}

Description: P1 (negative control), P2 (positive control), P3 (ethanol extract of henna leaves $200 \mathrm{mg} / \mathrm{kg} \mathrm{BW}$ ), $\mathrm{P}_{4}$ (ethanol extract of henna leaves $400 \mathrm{mg} / \mathrm{kg} \mathrm{BW}$ ), $\mathrm{P}_{5}$ (ethanol extract of henna leaves $600 \mathrm{mg} / \mathrm{kg} \mathrm{BW}$ ).

Similarly, Morakinyo et al. (2011) confirmed that SOD activity in diabetic mice given ginger ethanol extract (Zingiber officinale) was higher than control diabetes mice. Flavonoids contained in ginger ethanol extract (Zingiber officinale) can increase the activity of superoxide dismutase enzymes. Srividya et al., (2010) added that there was an increase in SOD activity in diabetic mice treated with galang extract (Alpinia galanga). mutase (SOD) enzyme activity of male wistar mice blood after treatment for 28 days were shown in Table 1.

The results showed that giving ethanol extract of henna leaf had no difference of significant increase to the the activity of enzyme superoksida dismutase (SOD) wistar mice. The highest increase in superoxide dismutase (SOD) activity of wistar mice was found in $\mathrm{P}_{4}$ group, indicating that the $\mathrm{SOD}$ in $\mathrm{P}_{4}$ group increased toward $\mathrm{P}_{1}$ group compared to $\mathrm{P}_{2}, \mathrm{P}_{3}$ and $\mathrm{P}_{5}$ groups. Superoxide dismutase was the body's leading defense against the activation and toxicity of free radical compounds (Astuti et al., 2009). Increasing SOD activity after giving ethanol extract of henna leaves containing polyphenolic compounds; flavonoids. 
Indonesian Journal of Medicine (2017), 2(2): 79-85

https://doi.org/10.26911/theijmed.2017.02.02.01

The ethanol extract of henna leaves $400 \mathrm{mg} / \mathrm{kg} \mathrm{BW}$ with a dose of leaf ethanol significantly decreased the blood glucose level of wistar mice and there was no significant difference in the activity of Superoxide Dismutase (SOD) enzyme on the group treated with ethanol extract of henna leaf.

\section{REFERENCE}

American Diabetes Association (2014).

Position Statement: Diagnosis and classification of diabetes mellitus. Diabetes Care, 37(S1): 81-90.

Astuti S, Muchtadi D, Astawan M, Purwantara B, Wresdiyati $\mathrm{T}$ (2009). Pengaruh Pemberian Tepung Kedelai Kaya Isoflavon Terhadap Kadar Malondialdehid (MDA), Aktivitas Superoksida Dismutase (SOD) Testis dan Profil $\mathrm{Cu}, \mathrm{Zn}-$ SOD Tubuli Seminiferi Testis Tikus Jantan. J. Teknol. Dan Industri Pangan, 20(2): 129-134.

Chikaraddy A, Maniyar Y, Mannapur B (2012). Hypoglycemic Activity of Ethanolic Extract of Lawsonia inermis Linn. (Henna) in Alloxan Induced Diabetic Albino Rats. International Journal of Pharmacy and Biological Sciences, 2(4): 287-292.

Choubey A (2010). Hypoglycemic and Antihyperglycemic Effect of Ethanolic Extract of Whole. International Journal of Pharmaceutical Sciences and Study, 1(8): 74-77.

Cing J (2010). Potensi Antihiperglikemia Ekstrak Kulit Kayu Mahoni (Swietenia macrophylla King) pada Tikus yang Diinduksi Aloksan. Institute Pertanian Bogor.

Gayatri (2012). Anti-Diabetes and Hypoglycaemic Properties of Hemigraphis colorata in Rats. International Journal of Pharmacy and Pharmaceutical
Sciences, 4(2): 4-8.

Goswami M, Kulshreshtha M, Rao CV, Yadav S, Yadav S, Goswami M (2011). Anti-ulcer potential of Lawsonia inermis l. Leaves against gastric ulcers in rats. Journal of Applied Pharmaceutical Science,1(2): 69-72.

Goyal SN, Reddy NM, Patil KR, Nakhate KT, Ojha S, Patil CR, Agrawal YO (2016). Challenges and issues with streptozotocin-induced diabetes - A clinically relevant animal model to understand the diabetes pathogenesis and evaluate therapeutics. Chemico-Biological Interactions, 244: 49-63

Harborne JB (1984). Phytochemical Methods: A Guide to Modern Techniques of Plant Analysis (Second Edi). USA: Chapman and Hall Ltd.

Hsouna AB, Trigui M, Culioli G, Blache Y, Jaoua S (2011). Antioxidant constituents from Lawsonia inermis leaves: Isolation, structure elucidation and antioxidative capacity. Food Chemistry, 125(1): 193-200.

Jameson JL (2010). HARRISON'S Endocrinology. (P. J. Larry Jameson, MD, Ed.) (2nd editio). The McGraw Companies, Inc.

Kothari S, Thompson A, Agarwal A, Plessis SS (2010). Free radicals: Their beneficial and detrimental effects on sperm function. Indian Journal of Experimental Biology, 48: 425-435.

Kurkcu R (2010). The effects of shortterm exercise on the parameters of oxidant and antioxidant system in handball players. African Journal of Pharmacy and Pharmacology, 4: 448-452.

Lukiati B (2012). Profil Distribusi iNOS dan Kadar NO Pankreas Tikus Diabetes Mellitus Hasil Induksi 
MLD-STZ Pas-ca Pemberian Ekstrak Etanol Temugiring. Jurnal Kedokteran Hewan, 6(2): 120-124.

Ojewunmi O, Oshodi T, Ogundele O, Micah C, Adenekan S (2013). In vitro Antioxidant, Antihyperglycaemic and Antihyperlipidaemic Activities of Ethanol Extract of Lawsonia inermis Leaves. British Journal of Pharmaceutical Study, 4(3): 301314 .

Prameswari OM, Widjanarko SB (2014). Uji Efek Ekstrak Air Daun Pandan Wangi Terhadap Penurunan Kadar Glukosa Darah dan Histopatologi Tikus Diabetes Melitus. Jurnal Pangan Dan Agroindustri, 2(2): 1627.

Rahmawati G, Rachmawati FN, Winarsih, H (2014). Aktivitas Superoksida Dismutase Tikus Diabetes yang Diberi Ekstrak Batang Kapulaga dan Glibenklamid. Scripta Biologica, 1(3): 19-23.

Ridwan A, Astrian RT, Barlian A (2012). Pengukuran Efek Antidiabetes Polifenol (Polyphenon 60) Berdasarkan Kadar Glukosa Darah dan Histologi Pankreas Mencit (Mus musculus L.) S. W. Jantan yang Dikondisikan Diabetes Mellitus. Journal Matematika Dan Sains, 17(2).

Sanni S, Thilza IB, Ahmed MT, Sanni FS, Talle M, Okwor GO (2010). The effect of aqueous leaves extract of henna (Lawsonia inermis) in carbon tetrachloride induced hepato-toxici- ty in swiss albino mice. Academia Arena, 2(6): 87-89.

Sheikhpour R (2013). Diabetes and Oxidative Stress: The Mechanism and Action. Iranian Journal of Diabetes and Obesity, 5(1): 40-45.

Siahaan JM, Harahap U (2016). Effect of Ethanol Extract of Chayote (Sechiumedule. Jacq. Swartz) on the Activity of Glutathione Peroxide (GPx) in House Mice (Musmusculus L) Strain DD Webster Hyperglycemia Induced by Streptozotocin (STZ). Indonesian Journal of Medicine, 1 : 47-52.

Stangeland T, Remberg SF, Lye KA (2009). Total antioxidant activity in 35 Uganda fruits and vegetables. Food Chemistry, 113(1): 85-91.

Suarsana IN (2010). Profil Glukosa Darah dan Ultrastruktur Sel Beta Pankreas Tikus yang Diinduksi Senyawa Aloksan. JITV, 15(2): 118-123.

Suarsana IN, Utama IH, Agung IG, Suartini A (2011). Pengaruh Hiperglikemia dan Vitamin E pada Kadar Malonaldehida dan Enzim Antioksidan Intrasel Jaringan Pankreas Tikus. MKB, 43(2): 72-76.

Sunyoto (2015). Pengaruh Pemberian Campuran Bee Pollen, Rimpang Kencur, Kunyit, Biji Pinang dan Kayu Manis Terhadap Kadar Gula Darah pada Tikus Wistar Pasca Paparan Streptozotocin. The 2nd University Study Coloquium, 389398. 